\title{
Chironomidae (Insecta: Diptera) of different habitats and microhabitats of the Vacacaí-Mirim River microbasin, Southern Brazil
}

\author{
RODRIGO KÖNIG ${ }^{1}$ and SANDRO SANTOS ${ }^{2}$ \\ ${ }^{1}$ Departamento de Ciências Biológicas, Instituto Federal Farroupilha, \\ Campus Júlio de Castilhos, Rodovia RS 527, s/n, 98130-000 Júlio de Castilhos, RS, Brasil \\ ${ }^{2}$ PPG Biodiversidade Animal, Departamento de Biologia, Universidade Federal de Santa Maria, \\ Av. Roraima, 1000, Bairro Camobi, 97105-900 Santa Maria, RS, Brasil \\ Manuscript received on October 10, 2011; accepted for publication on March 12, 2012
}

\begin{abstract}
The Chironomidae family is one of the main groups of aquatic insects present in streams. This work aimed to investigate the influences of anthropogenic pressures and substrate types on chironomid community composition and structure. Chironomid larvae were collected during the summer of 2007 at four sites along the Vacacaí-Mirim River microbasin, chosen based on the different available benthic substrates. The organisms were identified in the laboratory at the genus level, and the density, the rarefied taxonomic richness and the Shannon diversity index were calculated. The faunal structure was subjected to an ANOVA to compare the metrics among sites and substrates. The community composition of the sites was subjected to a multivariate statistical analysis. Differences in the composition, richness, density, and diversity were observed among the sites due to differences in the levels of nutrients and solids generated by the presence of crops close to water bodies. Samples collected from sandy substrates exhibited a lower density and taxonomic richness because sand is a poorer substrate than the others that were sampled. In organic or mixed substrates with higher energy availability and better shelter conditions, the observed densities were higher. The physical and chemical conditions and the morphometric characteristics of the sites were more influential than the substrates.
\end{abstract}

Key words: aquatic insects, benthic substrates, anthropogenic pressures, faunal structure.

\section{INTRODUCTION}

The patterns of diversity for organisms in aquatic environments have received considerable attention from researchers in recent years because, along with abiotic environmental factors, the data on these patterns can indicate the conservation status of a river, stream or other water body (Fesl 2002). Any environmental disturbance to a water body

Correspondence to: Rodrigo König

E-mail: konig_rodrigo@hotmail.com may affect the structure (density, abundance, and diversity) of distinct biological communities, such as the benthic macroinvertebrates.

Among the macroinvertebrates, Chironomidae (Diptera) larvae are predominant in freshwater environments (Armitage et al. 1995, Brito Jr et al. 2005). Immature stages of Chironomidae generally live on or in the sediment, feeding on organic detritus and associated microfauna and flora. This group occupies an important position in aquatic 
ecosystem trophodynamics, recycling nutrients in the sediment and modifying the composition of particulate organic matter (Sankarperumal and Pandian 1992).

The composition of a Chironomidae community changes based on alterations in trophic, physical and chemical conditions. Anthropogenic impacts frequently affect those conditions. Natural features may also shape the patterns of diversity in aquatic environments, with the substrate being one decisive factor (Henriques-Oliveira et al. 2003). Substrates containing more complex structures, such as leaves and wood, usually shelter a greater diversity of taxa compared with simple substrates, such as sand or rocks (Vinson and Hawkins 1998). Studies of the distribution of Chironomidae taxa may generate additional information that would be of use in the assessment of aquatic systems, e.g., data that indicate the influence of disturbances to the substrate, on hydrological variables and on edge vegetation, among others (Kleine and Trivinho-Strixino 2005).

The number of chironomid species in the Neotropical zone has been underestimated, taking into consideration the high diversity of the group (Spies and Reis 1996). Therefore, in this zone, in addition to the challenges posed by the interpretation of Chironomidae diversity patterns, there is also a need to further develop the taxonomic understanding of the group (Pannata et al. 2006).

In Southern Brazil, some segments of the Vacacaí-Mirim River microbasin are located in urban zones and in areas of agricultural influence, whereas some of its affluents have springs located on the edges of Serra Geral, a conservation area with good water quality. Such characteristics make this basin ideal for studies associating the characteristics of macro and micro environments with the structure of the Chironomidae community. The aim of this study was to investigate the influences of anthropogenic pressures and of substrate types on chironomid community composition and structure, as well as correlate the results with the environmental characteristics of the study areas and identify the factors that most influence the local fauna.

\section{MATERIALS AND METHODS}

The area studied is part of the Vacacaí-Mirim River's hydrographic microbasin, which drains a total area of $11,077 \mathrm{~km}^{2}$ (SEMA 2010). Together with the Vacacaí River microbasin, this constitutes one of the biggest hydrographic basins of the State of Rio Grande do Sul, Brazil. The climate is subtropical with an annual average temperature of $19.1^{\circ} \mathrm{C}$ and an annual average rainfall of $1,712 \mathrm{~mm}$ (Sutili et al. 2009, Heldwein et al. 2009).

Four sampling sites were selected within the Vacacaí-Mirim River microbasin in the Santa Maria municipality. The segments varied from first-order to third-order. Sites A and B displayed environmental characteristics with less human influence, whereas sites $C$ and D were influenced by areas of rice cultivation located close to the water body.

\section{DATA COLLECTION}

Chironomidae fauna were collected during the summer of 2007 , at the time when agricultural activities in the region reach their maximum (Baumart and Santos 2010). Samples were collected with a Surber sampler with a $0.25 \mathrm{~mm}$ mesh net and a collection area of $0.1 \mathrm{~m}^{2}$. A distinct number of samples were collected from each site to represent all of the substrates present in each area. The types of substrates varied according to site; however, with the exception of site $\mathrm{D}$, all sites included areas of rocks, leaves, and mixed substrate (organic and inorganic). A total of 26 samples were collected:

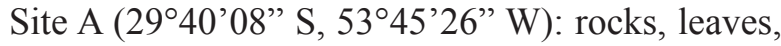
mixed (rocks/leaves).

Site B $\left(29^{\circ} 40^{\prime} 27^{\prime}\right.$ S, $\left.53^{\circ} 45^{\prime} 05^{\prime \prime} \mathrm{W}\right)$ : rocks, sand, leaves, mixed (rocks/leaves).

Site C (2940'58” S, 5343'46” W): rocks, leaves, mixed (rocks/leaves).

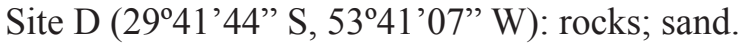


At least two samples representing each substrate were collected from each site. The collected sediment was stored in plastic bags and fixed with a formaldehyde solution at 5\%. At the laboratory, the material was sorted by size using a series of sieves. The residue was examined under a stereomicroscope. Semi-permanent slides were manufactured according to Trivinho-Strixino and Strixino's guide (1995), which was used to identify specimens along with the Epler guide (2001).

For every site and substrate, several abiotic variables were determined:

- In situ: water current velocity was measured with the use of a floater, according to Martinelli and Krusche (2004); pH was determined with an Ohaus $\mathrm{pH}$ meter; electrical conductivity was determined using a Marte MB-11P conductivimeter; and dissolved oxygen was measured with a Diginet oxymeter;

- In the laboratory: the total solids present in water samples were measured via gravimetry; the total nitrate and phosphate contents of water samples were determined using the spectrophotometric method; and the organic matter content of sediment samples was analyzed based on ash-free dry mass.

All analyses were performed according to procedures described in the Standard Methods for the Examination of Water and Wastewater (APHA 1998).

\section{DATA ANALYSIS}

The average density (number of individuals per $\mathrm{m}^{2}$ ) of chironomid taxa was determined for each site and substrate. Using the Biodiversity Pro program (Mcalecee et al. 1997), the rarefied taxonomic richness and the Shannon diversity index were also established, following Magurran (1988).

The UPGMA method and the Bray-Curtis distance were used to produce a dendrogram of the samples with the use of the biological matrix. In this way, we were able to verify whether the classifications were made based on site or substrate. Four types of substrates were considered: rocks, sand, organic (leaves), and mixed substrate (organic and inorganic).
To determine whether there were differences in the community structure (richness, density, and diversity), an analysis of variance (two-way ANOVA) was applied, including site and substrate factors. A multivariate analysis of variance (MANOVA) was applied to identify any differences in the community compositions of the samples.

The relative importance of site versus substrate was assessed based on a partial canonical correspondence analysis (pCCA). This analysis used the taxa density matrix to partition the results into independent components, revealing the percentage of the results that is explained by the spatial component (site), the percentage explained by the substrate type, the fraction that is shared (attributable to both site and substrate), and the fractionthatisundetermined.Twodifferentcanonical correspondence analyses (CCA) were processed separately to assess the association between taxa and sites, and between taxa and substrates. Taxa with an average density representing below $0.2 \%$ of the total fauna were discarded for the CCA. The "vegan" package (Oksanen et al. 2010) of the R program (R Development Core Team 2010) was used for the above analyses.

\section{RESULTS}

A total of 6,577 chironomid larvae were identified. Members of the Chironominae, Orthocladiinae and Tanypodinae subfamilies were collected from all sites, but a greater density of these subfamilies was present at site $\mathrm{C}$. The average proportions of the total larvae were $48 \%$ Chironomidae, $32 \%$ Orthocladiinae, and 20\% Tanypodinae. A total of 29 Chironomidae taxa were collected (Table I). Rheotanytarsus, Cricotopus, Thienemannimyia, and Polypedilum were the most abundant taxa.

The dendrogram generated from the biological matrix exhibited a strong tendency to structure the communities based on the site (Figure 1), although there was a tendency for identical substrates to be grouped together within the same site. 
TABLE I

The absolute average density (number of larvae $\mathrm{m}^{-2}$ ) of Chironomidae genera in the sampling sites and substrates of the Vacacaí-Mirim River microbasin, Santa Maria, Brazil.

\begin{tabular}{|c|c|c|c|c|c|c|c|c|c|c|c|c|}
\hline \multirow{2}{*}{$\begin{array}{c}\text { Site } \\
\text { Substrate }\end{array}$} & \multicolumn{3}{|c|}{$\mathbf{A}$} & \multicolumn{4}{|c|}{ B } & \multicolumn{3}{|c|}{$\mathbf{C}$} & \multicolumn{2}{|c|}{ D } \\
\hline & $\mathbf{R}$ & $\mathbf{O}$ & M & $\mathbf{S}$ & $\mathbf{R}$ & $\mathbf{O}$ & $\mathbf{M}$ & $\mathbf{R}$ & $\mathbf{O}$ & $\mathbf{M}$ & $\mathbf{R}$ & $\mathbf{S}$ \\
\hline \multicolumn{13}{|l|}{ Chironominae } \\
\hline Apedilum & & & & & & & & & & & $\mathrm{O}$ & \\
\hline Caladomyia & & & & & & $\mathrm{O}$ & $\mathrm{O}$ & & & & & \\
\hline Chironomus & $\mathrm{O}$ & & $\mathrm{X}$ & & & & & $\mathrm{X}$ & $\square$ & $\square$ & $\mathrm{X}$ & $\mathrm{X}$ \\
\hline Cryptochironomus & & & & & $\mathrm{O}$ & $\mathrm{O}$ & $\mathrm{O}$ & & & & $\square$ & $\square$ \\
\hline \multicolumn{13}{|l|}{ Dicrotendipes } \\
\hline Endotribelos & & & & & & $\mathrm{O}$ & & & & & & \\
\hline Harnischia & & $\mathrm{X}$ & $\mathrm{X}$ & & & $\mathrm{O}$ & $\mathrm{O}$ & & & & & \\
\hline Kiefferulus (?) & & & & & & & & & & & $\mathrm{O}$ & \\
\hline Parachironomus & & & & & & & & & & & $\square$ & $\square$ \\
\hline Paratendipes & & $\mathrm{X}$ & $\mathrm{X}$ & & & & & & & & & \\
\hline Polypedilum & $\mathrm{X}$ & $\mathrm{X}$ & $\square$ & $\square$ & $\square$ & $\Delta$ & $\Delta$ & $\square$ & $\square$ & $\Delta$ & $\mathrm{O}$ & $\mathrm{O}$ \\
\hline Rheotanytarsus & $X$ & $\mathrm{X}$ & $\mathrm{X}$ & $\mathrm{X}$ & $\square$ & $\square$ & $\square$ & $\Delta$ & $\Delta$ & $\Delta$ & $\Delta$ & $\square$ \\
\hline Stenochironomus & & & & & $\mathrm{O}$ & & & & & & & \\
\hline Tanytarsus & & & & $\mathrm{X}$ & & $\square$ & $\square$ & & & & & \\
\hline Tanytarsini type I & & & & & & & $\mathrm{O}$ & & & & & \\
\hline \multicolumn{13}{|l|}{ Orthocladiinae } \\
\hline Corynoneura & & & & $\mathrm{X}$ & $\square$ & $\square$ & $\mathrm{X}$ & & & & & \\
\hline Cricotopus & $\mathrm{X}$ & $\mathrm{X}$ & $\mathrm{X}$ & $\square$ & $\square$ & $\square$ & $\square$ & $\Delta$ & $\Delta$ & $\Delta$ & $\mathrm{X}$ & $\mathrm{X}$ \\
\hline Lopescladius & $\square$ & $\square$ & $\square$ & & $\square$ & $\square$ & $\mathrm{X}$ & & & & & \\
\hline Nanocladius & & & & $\mathrm{O}$ & $\mathrm{O}$ & & & & & & $\mathrm{O}$ & $\mathrm{X}$ \\
\hline Parametriocnemus & $\square$ & $\square$ & $\Delta$ & & & $\mathrm{O}$ & & & & & & \\
\hline Rheocricotopus & $\mathrm{O}$ & $\mathrm{X}$ & $\mathrm{X}$ & & $\mathrm{X}$ & & $\mathrm{O}$ & & & & & \\
\hline Thienemanniella & $\mathrm{X}$ & $\mathrm{X}$ & $\mathrm{X}$ & $\mathrm{O}$ & $\square$ & $\square$ & $\square$ & $\square$ & $\Delta$ & $\Delta$ & $\mathrm{X}$ & $\mathrm{X}$ \\
\hline \multicolumn{13}{|l|}{ Tanypodinae } \\
\hline Ablabesmyia & & & & $\mathrm{X}$ & $\square$ & $\mathrm{X}$ & $\square$ & & & & $\mathrm{O}$ & $\mathrm{O}$ \\
\hline Labrundinia & $\mathrm{X}$ & $\mathrm{X}$ & $\mathrm{X}$ & & $\mathrm{X}$ & $\mathrm{X}$ & $\mathrm{X}$ & & & & & \\
\hline Larsia & $\mathrm{X}$ & $\mathrm{X}$ & $\mathrm{X}$ & & $\square$ & $\mathrm{X}$ & $\mathrm{X}$ & $\mathrm{X}$ & $\mathrm{X}$ & $\mathrm{X}$ & $\mathrm{X}$ & \\
\hline Pentaneura & $\square$ & $\square$ & $\square$ & & $\mathrm{X}$ & & $\mathrm{X}$ & & & & & \\
\hline Thienemannimyia & $\mathrm{O}$ & $\mathrm{X}$ & $\mathrm{X}$ & $\square$ & $\square$ & $\square$ & $\square$ & $\Delta$ & $\Delta$ & $\Delta$ & $\square$ & $\mathrm{X}$ \\
\hline Zavrelimyia & & & & & & & $\mathrm{O}$ & & & & & \\
\hline Pentaneurini type I & & & & & & & $\mathrm{O}$ & & & & & \\
\hline
\end{tabular}

R: Rocky; O: Organic; M: Mixed; S: Sandy. O: 0-20; X: 21-100; $\square: 101-500 ; \Delta$ : >500.

Chironomid densities were higher at site C. At the sites where organic and mixed substrates were found, was observed a higher density of organisms compared to the other substrates. The rocky substrate exhibited a slightly lower density than the mixed and organic substrates. The sandy substrate indicated the lowest average chironomid density in the study overall (Figure 2). The ANOVA 


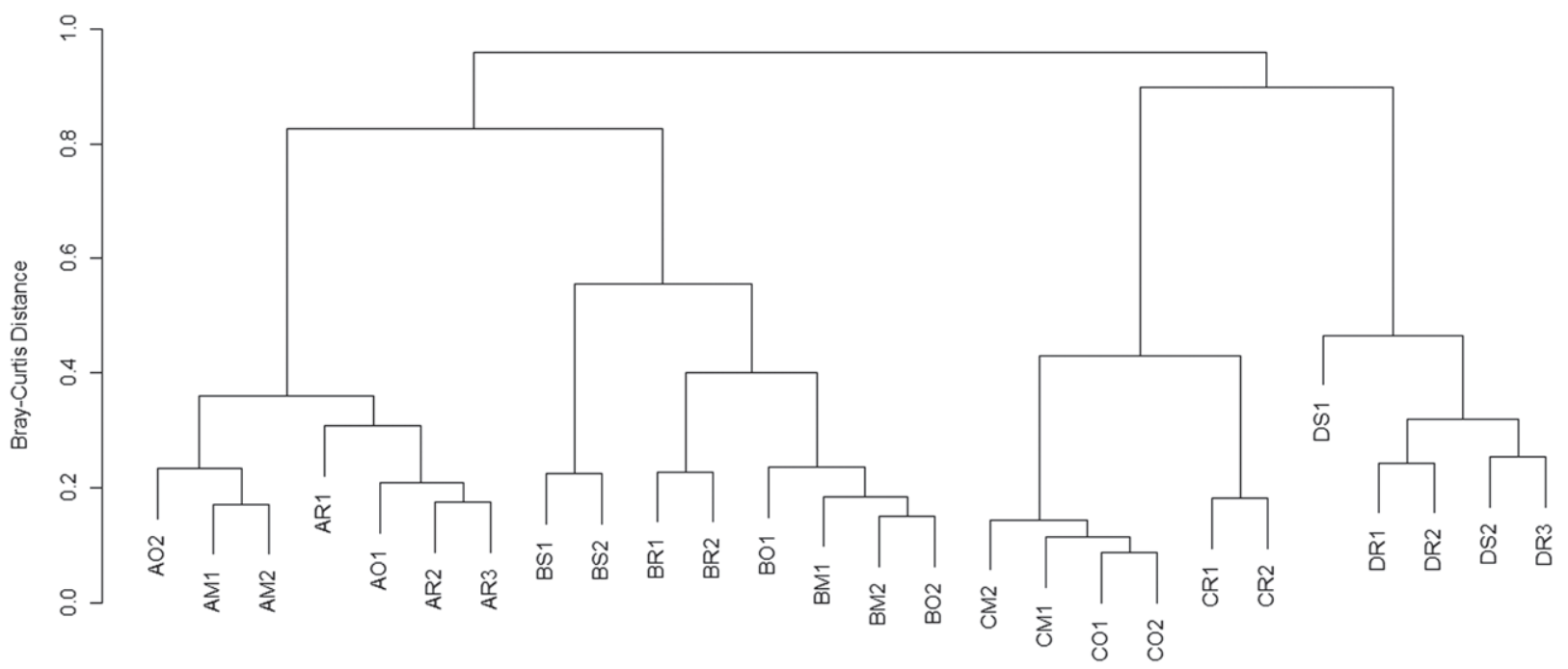

Figure 1 - Dendrogram displaying the sampling sites and substrates of the Vacacaí-Mirim River microbasin, Santa Maria, Brazil, created using cluster analysis with the UPGMA method and Bray-Curtis distance. Each branch in dendrogram corresponds to one replicate. The first letter indicates the sampling site and the second letter the substrate type: Organic (O), Mixed (M), Rocky (R), Sandy (S); numbers define substrate replicates (e.g., AO1 = sample number 1 of the organic substrate at site A).

test revealed significant differences in chironomid density among sites $(\mathrm{p}<0.01, \mathrm{~F}=455.241)$, among substrates $(\mathrm{p}<0.01, \mathrm{~F}=49.85)$, and for the site/ substrate interaction $(\mathrm{p}<0.01, \mathrm{~F}=26.57)$.

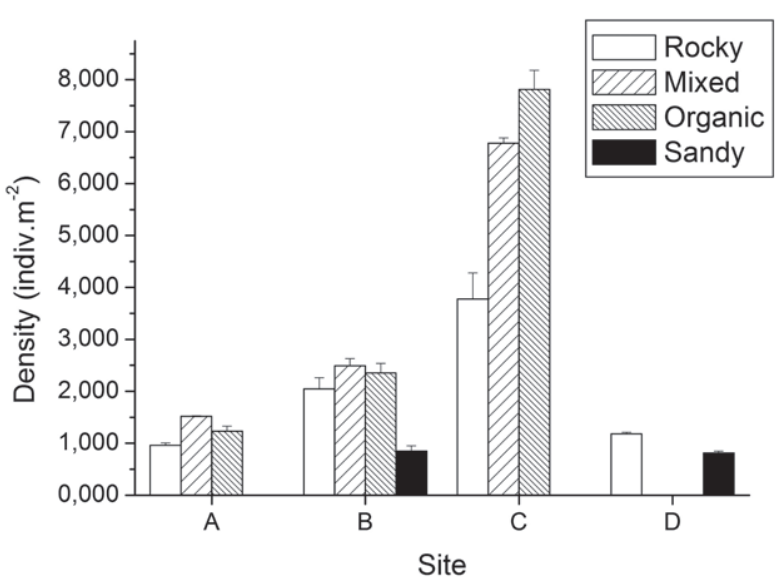

Figure 2 - Chironomidae density (ind. $\mathrm{m}^{-2}$ ) in the sampling sites and substrates of the Vacacaí-Mirim River microbasin, Santa Maria, Brazil. Horizontal bars indicate standard errors.

Taxonomic richness estimated using the technique of rarefaction revealed higher values for sites A and B (Figure 3). The same pattern occurred in the Shannon diversity index values (Figure 4). No patterns of richness or diversity were found within sites $\mathrm{A}, \mathrm{B}$ or $\mathrm{C}$ for the rocky, organic or mixed substrates. Sand had the lowest levels of richness and diversity in the sites where it was present. According to the ANOVA test, richness differed among sites $(\mathrm{p}<0.01, \mathrm{~F}=32.24)$ and for the site/substrate interaction $(\mathrm{p}<0.01, \mathrm{~F}=2.13)$, but not among substrates. The same pattern was observed for diversity $(\mathrm{p}<0.01, \mathrm{~F}=42.74$ for site; $\mathrm{p}<0.01, \mathrm{~F}=2.97$ for site/substrate).

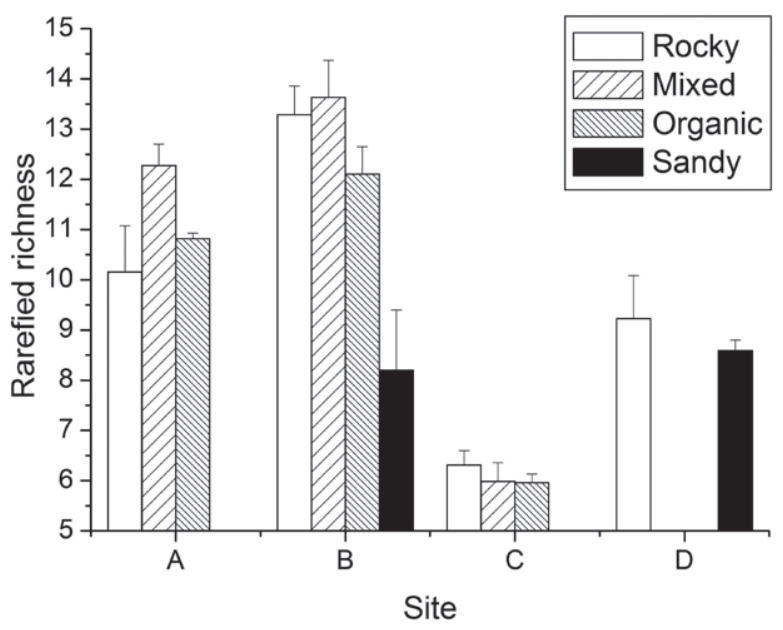

Figure 3 - Rarefied richness (number of taxa) in the sampling sites and substrates of the Vacacaí-Mirim River microbasin, Santa Maria, Brazil. Horizontal bars indicate standard errors. 


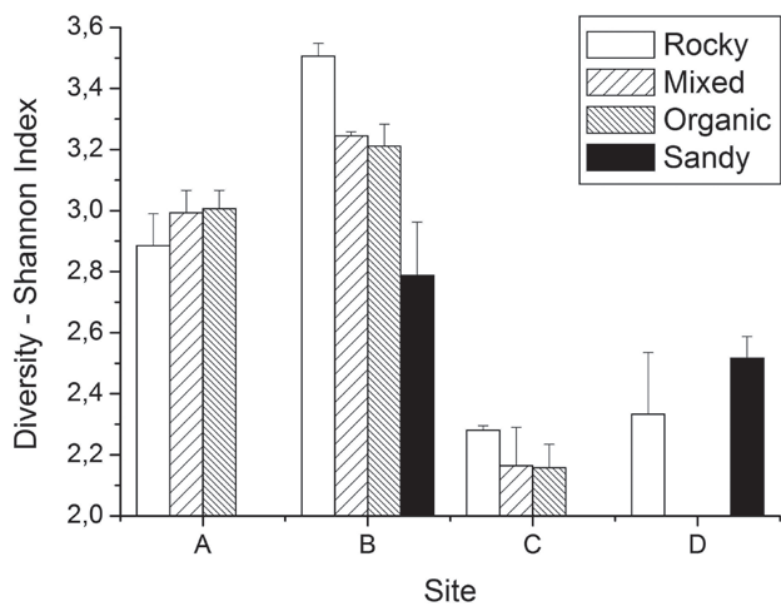

Figure 4 - Diversity (Shannon Index) of the Chironomidae fauna in the sampling sites and substrates of the VacacaíMirim River microbasin, Santa Maria, Brazil. Horizontal bars indicate standard errors.
The multivariate analysis used to compare faunal composition revealed differences among sites $(\mathrm{p}<0.01, \mathrm{~F}=25.53)$, substrates $(\mathrm{p}<0.01, \mathrm{~F}=$ $2.90)$, and site/substrate $(\mathrm{p}<0.05 ; \mathrm{F}=2.39)$.

According to the pCCA, the site explains $24.1 \%$ of the variation found among samples in the study, whereas the substrate explains only $4.3 \%$. The value of clarification shared by the two factors was $2.3 \%$.

The first two axes of the CCA based on site explain $79.2 \%$ of the total variance in the data (Figure 5). Axis 1 explains $50.5 \%$ of the variance, and it was positively correlated with high values for nutrient content (phosphate and nitrate), electrical conductivity, total solids, organic matter, and water

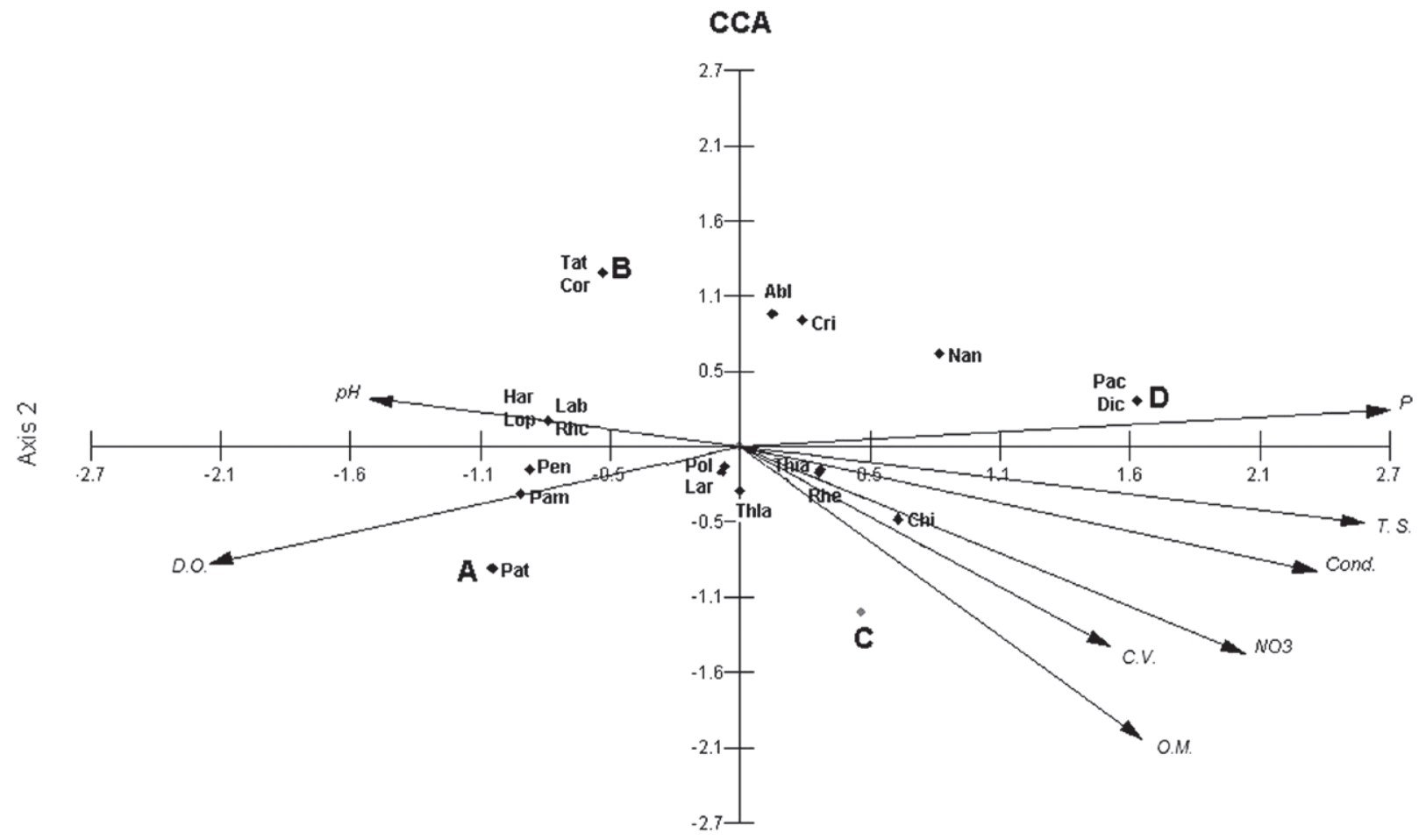

Vector scaling: 2.73

Axis 1

Figure 5 - Ordination diagram of the CCA with the abiotic variables and the most representative Chironomidae genera found in the sampling sites of Vacacaí-Mirim River microbasin, Santa Maria, Brazil. Abl (Ablabesmyia); Cri (Cricotopus); Nan (Nanocladius); Pac (Parachironomus); Dic (Dicrotendipes); Chi (Chironomus); Rhe (Rheotanytarsus); Thia (Thienemannimyia); Thla (Thienemanniella); Lar (Larsia); Pol (Polypedilum); Pat (Paratendipes); Pam (Parametriocnemus); Pen (Pentaneura); Rhc (Rheocricotopus); Lop (Lopescladius); Lab (Labrundinia); Har (Harnischia); Cor (Corynoneura); Tat (Tanytarsus). P (Total Phosphate); T.S. (Total Solids); Cond. (Electrical Conductivity); NO3 (nitrate); C.V. (Current Velocity); O.M. (Organic Matter); D.O.(Dissolved Oxygen). 
current velocity, all of which were characteristics of sites C and D. Parachironomus, Dicrotendipes, and Nanocladius were the taxa associated with this axis and with site D. Chironomus was associated with site $\mathrm{C}$.

Axis 2 explains $28.7 \%$ of the total variance, and it was correlated positively with $\mathrm{pH}$ and phosphate content. High oxygen concentrations were negatively projected on axes 1 and 2, especially associated with site A. Paratendipes was strongly associated with site A, whereas Tanytarsus and Corynoneura were associated with site B. To a lesser extent, Parametriocnemus, Pentaneura, Rheocricotopus, Lopescladius, Labrundinia, and Harnischia were also associated with these sites and/or conditions.

The first and second axes of the CCA generated for substrates (Figure 6) explain 80.7\% and $17.3 \%$ of the total variance, respectively. Larsia, Lopescladius, Rheocricotopus, Labrundinia, and Pentaneura were correlated with high values of current velocity and organic matter content. These variables and taxa were negatively associated with sandy substrates. Tanytarsus was negatively associated with rocky substrates. Harnischia and Paratendipes were strongly associated with mixed and organic substrates, whereas Nanocladius was associated with sand.

\section{DISCUSSION}

The present study comprises the first survey of Chironomidae fauna performed in the central region of Rio Grande do Sul. The total taxonomic richness found in this study area is similar to results found by other studies conducted in Brazil. Kleine and Trivinho-Strixino (2005) collected 33 Chironomidae taxa from three sampling sites in a river in São Paulo State (Brazil), 24 of which were collected in an environment located in a preservation area. It presented similar results to those of site B in the present study. Community structure can be influenced by environmental characteristics at different scales, such as those related to the

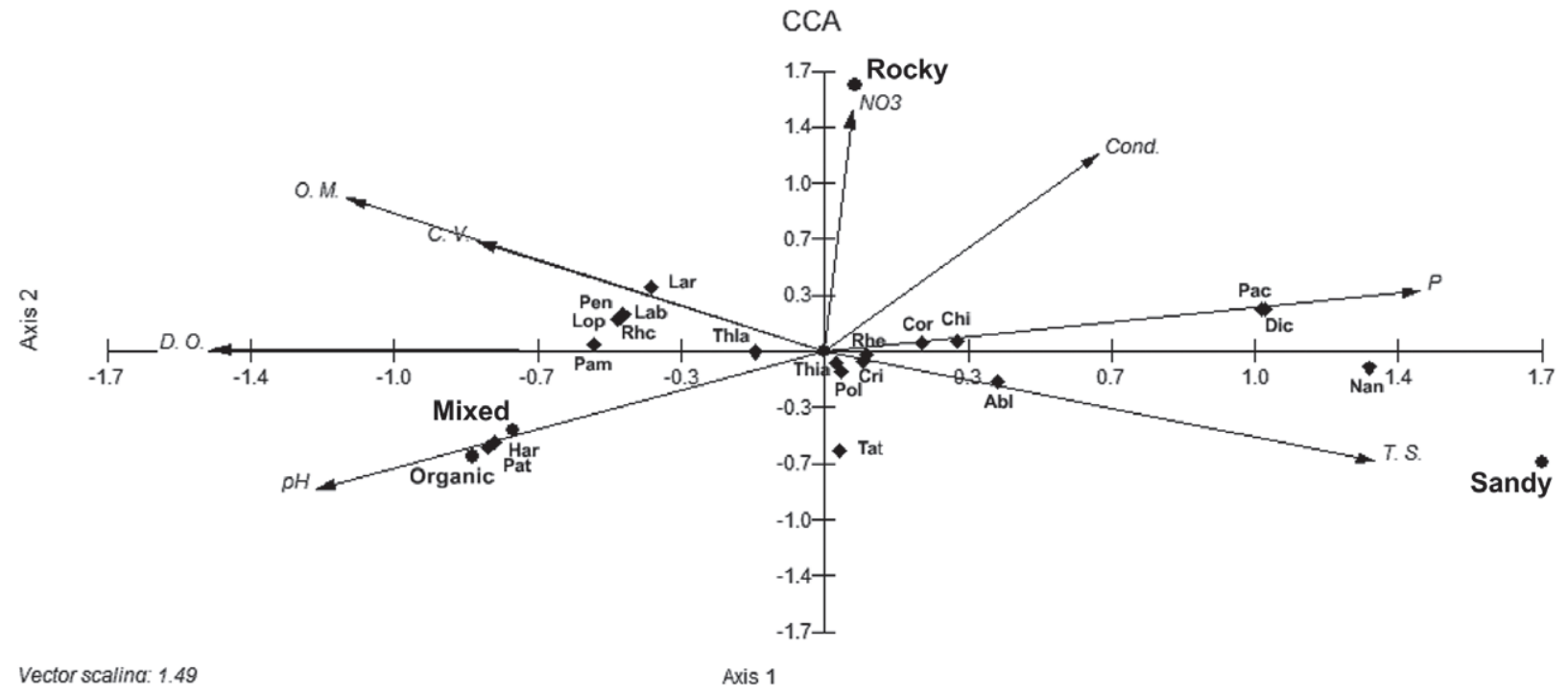

Figure 6 - Ordination diagram of the CCA with the abiotic variables and the most representative Chironomidae genera found in the sampling substrates of Vacacaí-Mirim River microbasin, Santa Maria, Brazil. Abl (Ablabesmyia); Cri (Cricotopus); Nan (Nanocladius); Pac (Parachironomus); Dic (Dicrotendipes); Chi (Chironomus); Rhe (Rheotanytarsus); Thia (Thienemannimyia); Thla (Thienemanniella); Lar (Larsia); Pol (Polypedilum); Pat (Paratendipes); Pam (Parametriocnemus); Pen (Pentaneura); Rhc (Rheocricotopus); Lop (Lopescladius); Lab (Labrundinia); Har (Harnischia); Cor (Corynoneura); Tat (Tanytarsus). P (Total Phosphate); T.S. (Total Solids); Cond. (Electrical Conductivity); NO3 (nitrate); C.V. (Current Velocity); O.M. (Organic Matter); D.O.(Dissolved Oxygen). 
site and/or microhabitats. In this study, we could observe that the general characteristics of the sites exerted a great influence over faunal distribution, with distinct types of substrates within the same environment ending up with more similarities than the same substrates in different environments.

The spatial distribution of aquatic insects is directly related to river current velocity, water temperature, dissolved oxygen, $\mathrm{pH}$, size of substrate particles, food availability, and other variables. Physical, chemical, and morphometric characteristics define the macro-distribution, whereas substrates and food availability tend to influence micro-distribution (Fesl 2002). Physical and chemical factors were determinant for Chironomidae fauna, and they can better explain the community distribution than substrate type, as revealed in the classification analysis and pCCA results.

Sites A and B exhibited the highest taxonomic diversity and richness. At these sites, the river is protected from impacts by the presence of riparian vegetation (Primack and Rodrigues 2001). Similar morphometric properties, such as low values for total solids, percentage of organic materials, electrical conductivity, and nutrients as well as a high level of dissolved oxygen, characterize sites A and B as the least-modified environments regarding physical and chemical characteristics. These attributes characterize well-preserved environments and low-order rivers. Some of the taxonomic groups found in these sites are considered sensitive to environmental disturbances, such as Paratendipes and Rheocricotopus (Ruse and Wilson 1995).

However, although sites A and B share similar physical and chemical attributes, they display unique characteristics in terms of taxonomic richness, diversity and faunal composition. According to Coffman (1995), highly heterogeneous rivers are usually associated with a greater abundance of species. Therefore, the variety of fauna observed at site B may be a result of the greater heterogeneity of habitats found in this environment.
Richness and diversity were significantly different at sites $\mathrm{C}$ and $\mathrm{D}$ compared to the other environments. Several site characteristics contributed to this dissimilarity, particularly the high levels of nutrients (nitrogen at site $\mathrm{C}$ and phosphate at site D) and organic matter, as well as the high-velocity water current. The recorded data for sites $\mathrm{C}$ and $\mathrm{D}$ regarding content of nutrients and organic matter characterize altered environments with low richness, because only highly tolerant groups can remain in such conditions. Tolerant taxa, such as Thienemannyimia, Cricotopus and Rheotanytarsus, sustained large populations, especially at site C. According to Amorim et al. (2004), environmental disturbances tend to promote an increase in biomass and a decrease in richness. Rheotanytarsus individuals were present in great numbers on the macrophyte plants at site $\mathrm{C}$. Those plants provide shelter and allow the taxon to exploit the fast-moving water of the site. Rheotanytarsus are collector-filterers (Merritt and Cummins 1996), and their way of getting food is favored from a high-velocity current (Sanseverino and Nessimian 2001, Kikuchi and Uieda 2005). The biological contrasts between the two groups of environments (sites C-D versus sites A-B) can easily be perceived. However, the sites also differ among themselves, as evidenced by faunal composition, another signal that spatiality can influence a community.

Some taxa were characteristic of less-disturbed sites, whereas others characterized more impacted ones. Roque et al. (2000) cited Corynoneura, Lopescladius, Harnischia, and Labrundinia among the taxa found in environmental conditions characterizing less-impacted areas. That trend was confirmed in this study, because those taxa were associated with sites A and/or B. However, other taxa were also related to less-disturbed environments, such as Parametriocnemus, Pentaneura, Rheocricotopus, and Tanytarsus. Dicrotendipes characterizes agricultural areas (Rae 1989) and it was found only at site D (influenced by 
rice cultivation). Parachironomus and Nanocladius were also typical of site $\mathrm{D}$, indicating a possible link with intermediate-quality water. Chironomus was associated with site $\mathrm{C}$, corroborating existing information about the relationship of this taxon with impacted water quality (Marques et al. 1999). Confirming another tendency in our data, Roque et al. (2000) suggested that the larvae of Rheotanytarsus and Polypedium can tolerate a wide range of environmental disturbances. Rheotanytarsus larvae were numerous at both of the sites that were enriched by nutrients (C and D), possibly due to the proximity of rice cultivation.

Even with the site exerting a greater influence on community structure than the substrate in the present study, it is well-established that the distribution of several groups of aquatic insects is defined according to the types of substrate available; this factor often determines the presence and abundance of various populations (Fend and Carter 1995). There are a number of notable tendencies in this study. Substrates primarily influenced the density and composition of the community. Substrates containing at least a fraction of organic matter generally exhibited greater chironomid density, corroborating the conclusions of Baptista et al. (2001) that such organic components, especially leaves, may be favorable because they provide better feeding and sheltering conditions in addition to having a richer periphytic flora. As the presence of leaves is typical in loworder rivers and Chironomidae are numerous in aquatic environments, the idea that a great number of organisms use leaves as a source of energy is plausible (Callisto and Gonçalves Jr 2007).

Among the recorded taxa, Polypedilum exhibited high densities across all substrates due to its cosmopolitan characteristics (Aburaya and Callil 2007), but the values were higher for vegetation or mixed substrates. Harnischia and Paratendipes also revealed a preference for these substrates, possibly because of the better food conditions offered.
Sand was the least inviting substrate for the development of Chironomidae fauna, presenting a lower amount of organic matter and a greater accumulation of solids than other substrates. It is likely that substrate instability linked to the low availability of organic matter in sandy substrates hindered taxonomic richness and organism density. Substrate stability is proportional to particle size; thus, smaller particles, such as those found in mostly sandy substrates, can be moved more easily (Tikkanen et al. 1994). Henriques-Oliveira et al. (2003) also reported lower taxonomic richness in sites characterized by greater quantities of sandy substrate.

It is also important to highlight the negative correlation between some taxa and sandy substrates. Larsia displayed this tendency more pronouncedly, and it was recorded in all substrates except sand. Labrundinia and Pentaneura densities declined sharply in sand. This trend does not corroborate Wiederholm's (1983) findings, which indicates a tendency for the subfamily Tanypodinae to be present in higher numbers in sandy substrates. One explanation may be the predation habit of the group (Wetzel 1993), which includes the intake of other chironomids. The decreased density in sandy substrates of groups that serve as food may have contributed to the lower abundance of these three Tanypodinae taxa in that substrate. Other taxa may also have been influenced by the conditions of the sandy substrate, such as Lopescladius and Rheocricotopus. Nanocladius was the only taxon that indicated a preference for sandy substrates.

The rocky substrate also supported a lower average Chironomidae density regarding organic substrates, but no meaningful difference concerning faunal richness was observed. Benthic communities are more stable in rocky areas than sandy areas. Communities in rocky substrates are controlled by biological interactions, whereas in sand, community structures are physically determined and therefore more susceptible to environment 
variations (Kikuchi and Uieda 2005). Neither of the groups exhibited a strong relationship with the rocky substrate, but the absence of Tanytarsus in this substrate, despite its high density in organic substrates, confirms the results of Sanseverino and Nessimian (1998), indicating that the larvae of this taxon primarily inhabit deposited litter. The presence of Stenochironomus in rocky substrates is unusual and most likely occurred accidentally, because this taxon is a miner of submerged leaves and wood fragments (Epler 2001). The spatial proximity between the substrates may have resulted in a mixture of plant debris colonized by Stenochironomus larvae in the rock sample, or these organisms may have been washed onto the rocky substrate by the current.

Future applied studies could confirm the potential utility of Chironomidae taxa as indicators of different anthropogenic disturbances and types of substrates, considering that in this study some groups occurred only in particular sites and microhabitats.

\section{ACKNOWLEDGMENTS}

This work was supported by grants provided by Pró-Publicações Internacionais/PRPGP/UFSM and by a MSc scholarship grant provided by the Coordenação de Aperfeiçoamento de Pessoal de Nível Superior (CAPES).

\section{RESUMO}

A família Chironomidae é um dos principais grupos de insetos aquáticos presentes em riachos. Este trabalho teve como objetivo investigar a influência de pressões antrópicas e do tipo de substrato sobre a estrutura e composição da comunidade de Chironomidae. Larvas de Chironomidae foram coletadas durante o verão de 2007 em quatro locais da microbacia do rio Vacacaí-Mirim, considerando os diferentes substratos bentônicos disponíveis. Os organismos foram identificados em laboratório até o nível de gênero e foi calculada a densidade, a riqueza taxonômica rarefeita e a diversidade de Shannon. A estrutura da fauna foi submetida à ANOVA para comparação das métricas entre locais e substratos. A composição da comunidade dos locais foi submetida à estatística multivariada. Diferenças na composição, riqueza, densidade e diversidade foram observadas nos locais, devido a diferentes níveis de nutrientes e sólidos gerados pela presença de culturas próximas aos corpos d'água. Amostras de substrato arenoso apresentaram menor densidade e riqueza por este ser um substrato mais pobre em relação aos demais amostrados. Em substratos orgânicos ou mistos, que tem maior disponibilidade de energia e melhores condições de abrigo, as densidades observadas foram maiores. Fatores físicos, químicos e morfométricos dos locais foram mais influentes do que as características dos substratos.

Palavras-chave: insetos aquáticos, substratos bentônicos, pressões antrópicas, estrutura da fauna.

\section{REFERENCES}

ABURAYA FH AND CALLIL CT. 2007. Variação temporal de larvas de Chironomidae (Diptera) no alto Rio Paraguai (Cáceres, Mato Grosso, Brasil). Rev Bras Zool 24: 565-572.

AMORIM RM, HENRIQUES-OLIVEIRA AL AND NESSIMIAN JL. 2004. Distribuição espacial e temporal das larvas de Chironomidae (Insecta: Diptera) na seção ritral do rio Cascatinha, Nova Friburgo, Rio de Janeiro, Brasil. Lundiana 5: 119-127.

APHA - American Public Health Association. 1998 Standart methods for the examination of water and wastewater. $20^{\text {th }}$ ed., Washington, $937 \mathrm{p}$.

ARMitage PD, Cranston PS AND PINDER LCV. 1995. The Chironomidae: Biology and ecology of non-biting midges, London: Chapman \& Hall, 572 p.

BAPTISTA DF, Buss DF, DORVILLÉ LFM AND NESSIMIAN JL. 2001. Diversity and habitat preference of aquatic insects along the longitudinal gradient of the Macaé River Basin, Rio de Janeiro, Brazil. Rev Brasil Biol 61: 249-258.

BAUMART JS AND SANTOS S. 2010. The Impact of Herbicides on Benthic Organisms in Flooded Ricefields in Southern Brazil. In: KORTEKAMP A (Ed), Herbicides and Environment. InTech, p. 369-382.

BRITO JR L, ABÍlIO FJP AND WATANABE T. 2005. Insetos aquáticos do açude São José dos Cordeiros (semi-árido paraibano) com ênfase em Chironomidae. Entomol Vec 12: 149-157.

CAllisto M AND GONÇAlves JR JF. 2007. Leaf litter as a possible food source for chironomids (Diptera) in Brazilian and Portuguese headwater streams. Rev Bras Zool 24: 442-448. 
COFFMAN WP. 1995. Conclusions. In: ARMITAGE PD, CRANSTON PS AND PINDER LCV (Eds), The Chironomidae: biology and ecology of non-biting midges, London: Chapman \& Hall, p. 436-447.

EPLER JH. 2001. Identification manual for the larval Chironomidae (Diptera) of North and South Carolina. A guide to the taxonomy of the midges of the southeastern United States, including Florida, Palatka: North Carolina Department of Environment and Natural Resources, 526 p.

FEND SV AND CARTER JL. 1995. The relationship of habitat characteristics to the distribution of Chironomidae (Diptera) as masured by pupal exuviae collection in a large river system. J Freshw Ecol 10: 343-359.

FESL C. 2002. Biodiversity and resource use of larval chironomids in relation to environmental factors in a large river. Freshwater Biol 47: 1065-1087.

Heldwein AB, Buriol GA AND Streck NA. 2009. O Clima de Santa Maria. Ciência \& Ambiente 38: 43-58.

HENRIQUES-OlIVEIRA AL, DORVILLÉ LFM AND NESSIMIAN JL. 2003. Distribution of Chironomidae larvae fauna (Insecta: Diptera) on different substrates in a stream at Floresta da Tijuca, RJ, Brazil. Acta Limnol Bras 15: 69-84.

KIKUCHI RM AND UIEDA VS. 2005. Composição e distribuição dos macroinvertebrados em diferentes substratos de fundo de um riacho no município de Itatinga, São Paulo, Brasil. Entomol Vect 12: 193-231.

KLEINE P AND TRIVINHO-STRIXINO S. 2005. Chironomidae and other aquatic macroinvertebrates of a first order stream: community response after habitat fragmentation. Acta Limnol Bras 17: 81-90.

MAgurRAN AE. 1988. Ecological diversity and his measurement, London: Princeton University Press, 179 p.

MARQues MMGSM, BARBosa FAR AND CALlisto M. 1999. Distribution and abundance of Chironomidae (Diptera) in impacted watershed in south-east Brasil. Rev Bras Biol 59: 553-561.

Martinelli LA AND KRUSCHE AV. 2004. Amostragem em Rios. In: BICUDO CEM AND BICUDO DC (Eds), Amostragem em Limnologia, São Carlos: RiMa, p. 263-279.

McAlecee N, LAmbSheah PJD, Paterson GLJ AND Gage JG. 1997. Bio Diversity Professional Beta-Version, London: The Natural History Museum and The Scottish Association for Marine Sciences.

MERRITT RW AND CUMmINS KW. 1996. Introduction to aquatic insect of North America, $3^{\text {rd }}$ ed., Iowa: Kendall/ Hunt Publishing Company, 862 p.

OKsanen J, Blanchet FG, Kindt R, LEgEndRe P, O'HARA RB, Simpson GL, SOlymos P, STEVENS MH AND WAGNER H. 2010. Multivariate Analysis of Ecological Communities in R: package "vegan". Available from http://vegan.rforge.r- project.org/

Panatta A, Sternet C, Freitas SMF And Maltchik L. 2006. Diversity of chironomid larvae in palustrine wetlands of the coastal plain in the south of Brazil. Limnol 7: 23-30.

Primack RB AND Rodrigues E. 2001. Biologia da conservação, Londrina: Planta, 327 p.
R Development Core TeAm. 2010. R: A language and environment for statistical computing. Vienna: $\mathrm{R}$ Foundation for Statistical Computing. Available from http://www.R-project.org.

RAE JG. 1989. Chironomidae midges as indicatores of organic pollution in the Scioto River Basin. Ohio J Sci 89: 5-9.

Roque FO, Corbi J AND TRIVINHO-STRIXINO S. 2000. Considerações sobre a utilização de larvas de Chironomidae (Diptera) na avaliação da qualidade da água de córregos do Estado de São Paulo. In: ESPÍNDOLA ELG, BOTTAPASCOAL CMR, ROCHA O, BOHRER MBC AND OLIVEIRA-NETO AL (Eds), Ecotoxicologia: Perspectivas para o Século XXI, São Carlos: RiMa, p. 115-123.

RUSE LP AND WILSON LP. 1995. Long-term assessment of water and sediment quality of the river Thaming using chironomidae pupal skins. In: CRASTON P (Ed), Chironomidae from genes to ecosystems, Melbourne: Csiro, p. 113-131.

SANKARPERUMAL G AND PANDIAN TJ. 1992. Larval abundance of Chironomus circumdatus in relation to biotic and abiotic factors. Hydrobiol 246: 205-212.

SANSEVERINO AM AND NESSIMIAN JL. 1998. Habitat preferences of Chironomidae larvae in an upland stream of Atlantic Forest, Rio de Janeiro State, Brazil. Verh Internat Verein Limnol 26: 2141-2144.

SANSEVERINO AM AND Nessimian JL. 2001. Hábitats de larvas de Chironomidae (Insecta, Diptera) em riachos de Mata Atlântica no Estado do Rio de Janeiro. Acta Limnol Bras 13: 29-38.

SEMA - Secretaria do Meio Ambiente do Estado do Rio GRANDE DO SUL. 2010. Bacia hidrográfica dos rios Vacacaí - Vacacaí Mirim. Available from http://www. sema.rs.gov.br/

SPIES M AND REIS F. 1996. Catalog and bibliography of Neotropical and Mexican Chironomidae (Insecta, Diptera). Spixiana 22: 61-119.

SUTILI FJ, DURLO MA AND BRESSAN DA. 2009. Hidrografia de Santa Maria. Ciência \& Ambiente 38: 79-92.

Tikkanen P, LaAsonen P, Muotka T, Huhta A AND KUUSELA K. 1994. Short term recovery of benthos following disturbance from stream habitat rehabilitation. Hydrobiol 273: 121-130.

TRIVINHO-STRIXINO S AND STRIXINO G. 1995. Larvas de Chironomidae (Diptera) do Estado de São Paulo: Guia de identificação e diagnose dos gêneros, São Carlos: PPGERN/UFSCar.

VINSON MR AND HAWKINS CP. 1998. Biodiversity of stream insects: variation at local, basin and regional scales. Annu Rev Entomol 43: 271-293.

Wetzel RG. 1993. Limnologia, Lisboa: Fundação Calouste Gulbenkian, 919 p.

Wiederholm T. 1983. Chironomidae of Holartic Region: keys and diagnoses. Part 1. Larvae. Entomologica Scandinavica, $457 \mathrm{p}$. 